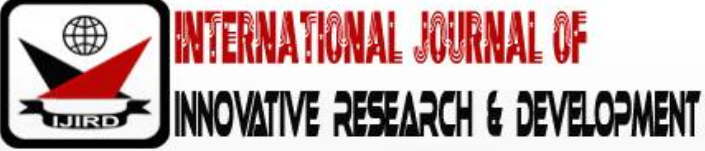

ISSN 2278 - 0211 (Online)

\section{The Effect of Performance Appraisal Systems and Compensation Systems on Work Motivation Mediated by Job Satisfaction of Yogyakarta Primary Tax Service Office Employees}

\author{
Harsono Kusumayuda \\ Student, Department of Education Department, Indonesian Islamic University, Indonesia
}

\begin{abstract}
:
The role of Human Resources (HR) is very important for the company, HR is one of the factors directly involved in the company's activities and is important in increasing company productivity in achieving the company's goals or targets. The company needs potential human resources both leaders and employees on the pattern of tasks and supervision that is a determinant of achieving the company's goals. HR is a central figure in organizations and companies. In order for management activities to run well, companies must have knowledgeable and highly skilled employees and efforts to manage the company optimally so that employee performance improves.

This study also aims to determine the effect of performance appraisal systems and compensation systems on work motivation, and job satisfaction in the Yogyakarta Primary Tax Service Office as a mediation of the relationship between performance appraisal systems and compensation systems with work motivation. Empirical results were obtained through distributing questionnaires to 109 employees of the Yogyakarta Primary Tax Service Office.

This research conducts structural equation modeling to test the proposed relationship. The results showed that the performance appraisal system and the compensation system had a positive and significant effect on job satisfaction and work motivation and job satisfaction can mediate a positive and significant relationship between performance appraisal systems and motivation that work at the Yogyakarta Primary Tax Service Office
\end{abstract}

Keywords: Human Resources (HR), performance appraisal system, compensation system, job satisfaction, and work motivation

\section{Introduction}

HR is a central figure in organizations and companies, so that management activities run well, companies must have knowledgeable and highly skilled employees and efforts to manage the company optimally so that employees' performance increases (Widodo, 2011). According to some literature, the success of an organization's performance can be influenced by the performance measurement system. HR factors must be guided, directed and driven to implement company goals; therefore, the company needs to form a performance measurement system. The establishment of a performance measurement system is expected to be useful to motivate employees to work and provide opportunities for employees to recognize, sharpen, develop, and convey initiative ideas and their thoughts and potential. In accordance with research by Naji et al., (2015), Cook (2004), Lira (2014) and Idowu (2017) which states that the performance measurement system has an important role in improving employee performance.

In addition to establishing a performance measurement system, it must be accompanied by a fair and proper compensation system. Compensation or remuneration programs generally aim to benefit the company and the employee itself. Providing compensation is one thing that is very important to achieve company goals. Efforts to achieve company goals need to have a compensation program to motivate employees to work better. If the services provided are large enough, the manager will easily motivate his subordinates (Hasibuan, 2008). The importance of the compensation system's role in enhancing HR is supported by several literatures namely Darma (2018), Morgesan, Campion and Maertz (2001), Ferreira and Baidya (2016) Schwab (1973), Rizal, Idrus Djumahir and Mintarti (2014).

In addition, the work motivation of employees is no less important both for employees themselves and for the company (Simamora, 2006). In encouraging motivation to improve performance, the provision of work motivation in KPP Pratama Yogyakarta needs to be done by providing work tasks and or challenges that are difficult to achieve and encourage motivation that can impact on work performance to subordinates. Yogyakarta Primary Tax Office also implements a job rotation system in completing tasks and mutations in order to adjust the expertise and abilities of each employee in work. In addition, the factors that influence employee work motivation are job satisfaction. In general, job satisfaction is colored by feelings towards the work environment situation and is a reflection of an employee's satisfaction 
with conditions related to the implementation of work (Robbins \& Mary, 2008). Employee dissatisfaction can occur if the work done is not in accordance with what is obtained from the company. The dissatisfaction of these employees raises undesirable things and can harm the company concerned. Therefore, employee job satisfaction must always be considered in order to bring a positive impact on the company that is reflected in the achievement of company goals.

The phenomenon that occurs in KPP Pratama Yogyakarta due to the large size of this institution, it requires a high level of support or motivation and of course good compensation from the company to employees in order to increase employee motivation. In addition, KPP Pratama Yogyakarta also implements a job rotation system in completing tasks and mutations in order to adjust the expertise and abilities of each employee in work. Performance measurement systems and compensation systems affect work motivation and job satisfaction mediates the effect of performance measurement and compensation on work motivation. This is supported by the results of research by Herpen et al., (2005) and Ainnisya \& Isnurrini (2018), Pribadi \& Dhyah (2014), Ngatemin \& Wanti (2013) and Haryani et al., (2015).

Research on performance measurement systems and compensation systems is already quite a lot but research that combines these two variables and measures motivation as mediating variables is still very little. Therefore, the author will discuss and study this problem in a study entitled "The Effect of Performance Measurement Systems and Compensation Systems on Work Motivation Mediated by Job Satisfaction of KPP Pratama Yogyakarta Employees".

\section{Literature Review}

\subsection{Effect of Performance Measurement Systems on Job Satisfaction}

An organization, both private and government, will always try to get members or employees involved in carrying out organizational activities. It can improve performance that is realized in the form of employee performance as high as possible to realize the goals of the organization. For this reason, skilled, professional and high-working human resources are the desire of all organizations. In general, job satisfaction is colored by feelings towards the work environment situation and is a reflection of an employee's satisfaction with conditions related to the implementation of work (Robbins \& Mary, 2008).

Employee dissatisfaction can occur if the work done is not in accordance with what is obtained from the company. The dissatisfaction of these employees raises undesirable things and can harm the company concerned. Therefore, employee job satisfaction must always be considered in order to bring a positive impact on the company that is reflected in the achievement of company goals. The research results of Herpen et al., (2005); Ukko et al., (2008); Souza \& Ilse (2018); Almohtaseb et al., (2017); Alvi \& Mehree (2013); Ying (2013) that the performance measurement system positively and significantly influences employee job satisfaction. The better the performance measurement system, the higher the level of employee satisfaction. Based on the description above, the hypotheses in this study are:

- H1: There is an influence of the performance measurement system on job satisfaction of KPP Pratama Yogyakarta employees.

\subsection{Effect of Compensation Systems on Job Satisfaction}

According to Simamora (2006) compensation is financial rewards and intangible services and benefits received by employees as part of employee relations. According to Newman (2005) that compensation refers to all forms of financial rewards as well as measured services and benefits that employees receive as part of an employment relationship. According to Hasibuan (2008) compensation is defined as all income in the form of money, direct or indirect goods received by employees in return for services provided to the company.

According to Handoko (2008) compensation is everything received by employees as compensation for subordinate work. Mondy (2008) states that compensation is the total reward received by employees in lieu of services that have been provided. Compensation is one of the factors that affect job satisfaction of an employee. Every organization should strive to improve the work satisfaction of its employees by providing fair and appropriate and competitive compensation programs. According to Madura (2001) factors that can affect job satisfaction include fair and proper compensation programs, job security, flexible work schedules, and employee engagement programs. Satisfaction with compensation is determined by fairness of compensation, level of compensation, and compensation administration practices. The research results of Herpen et al., (2005); Bakotić (2016); Rizal et al., (2016); Ghazanfar et al., (2011); Sudiardhita et al., (2018) that the compensation system positively and significantly influences employee job satisfaction. The better the compensation system, the higher the level of employee satisfaction.

- H2: There is an effect of the compensation system on job satisfaction of KPP Pratama Yogyakarta employees

\subsection{Effect of Performance Measurement Systems and Compensation Systems Together on Job Satisfaction}

Compensation is a major factor influencing an employee's job satisfaction. In certain conditions this opinion can be accepted, especially if it is associated with the large number of workers holding rallies to demand improvements to their salaries / wages. Many organizations provide high compensation, but do not always make employees satisfied. This shows that job satisfaction is not only influenced by the level of compensation received by employees, but by other factors. Compensation often triggers employee dissatisfaction. According to Siagian (2006) organizations should be able to create a compensation system that can encourage job satisfaction for their employees, which in turn will form a positive and productive attitude. Based on the results of research Caugemi \& Claypool (As'ad, 2002), found that the factors that cause job satisfaction are appreciation, praise, achievement, and promotion, while the factors that cause dissatisfaction are supervisors, working conditions, company policy, and salary. The research results of Herpen et al., (2005); Bakotić (2016); Rizal et al., (2016); Ghazanfar et al., (2011); Sudiardhita et al., (2018) that the performance measurement system and 
compensation system simultaneously affect employee job satisfaction. The better the performance measurement system and the compensation system together, the higher the level of employee satisfaction.

H3: There is an effect of the performance measurement system and the compensation system together on the job satisfaction of KPP Pratama Yogyakarta employees.

\subsection{Effect of Performance Measurement Systems on Motivation}

Performance measurement is related to employee work motivation where the implementation of performance measurement is expected to be useful to motivate employees to work and provide opportunities for employees in the aspects of extrinsic motivation and intrinsic motivation to recognize, sharpen, develop, and convey ideas of initiative and thoughts and their potential. It is hoped that the potentials of its employees will develop the best work performance for the development of the company and itself, especially to face the current era of globalization. Efforts to increase employee motivation, in addition to measuring performance must be accompanied by the provision of fair and appropriate compensation programs. The research results of Herpen et al., (2005); Ainnisya \& Isnurrini (2018); that performance measurement positively and significantly influences employee motivation. The better the performance measurement system, the higher employee motivation.

- H4: There is an effect of the performance measurement system on the work motivation of Yogyakarta KPP Pratama employees.

\subsection{Effect of Compensation Systems on Motivation}

Efforts to increase employee motivation, in addition to measuring performance must be accompanied by the provision of fair and appropriate compensation programs. Compensation programs on transparency, fairness, and controllability generally aim at the interests of the company and the employees themselves. So that these goals can be achieved and provide satisfaction for all parties, the compensation program should be based on the principles of fairness, fairness and compliance with labor laws. Providing compensation is one thing that is very important to achieve company goals. Efforts to achieve company goals need to have a compensation program to motivate employees to work better. If the services provided are large enough, the manager will easily motivate his subordinates (Hasibuan, 2008). The research results of Herpen et al., (2005); Ngatemin \&Wanti (2013); Haryani et al., (2015); Rizal et al., (2016) that the compensation system positively and significantly influences employee motivation and performance measurement and compensation systems simultaneously influence employee motivation. The better the compensation system, the higher work motivation of employees.

- H5: There is an effect of the compensation system on the work motivation of Yogyakarta KPP Pratama employees.

\subsection{Effect of Job Satisfaction on Motivation}

Job satisfaction is a reflection of one's feelings towards their work. Luthans (2005) in his book "Organizational Behavior" states that job satisfaction is a positive emotional state of someone arising from appreciation for something the work has done. It was further said that job satisfaction is the result of a person's achievements towards how well his work provides something useful to him. According to Handoko (Andini, 2006) job satisfaction is an emotional state that is felt pleasant or not by employees regarding their work. Rowland (Nursalam, 2008) states the manager's function of increasing staff job satisfaction is based on motivational factors which include: a desire to increase trust that the salary received is sufficient, has the ability of knowledge, skills and values needed, feedback, opportunities to try, Appearance instruments for promotion, cooperation and enhancing income. The research results of Herpen et al., (2005); Ngatemin \& Wanti (2013); Ukko et al., (2008); Souza \& Ilse (2018) that job satisfaction positively and significantly influences employee motivation. The better job satisfaction of employees, the higher work motivation of employees.

- H6: There is an influence of job satisfaction on the work motivation of Yogyakarta KPP Pratama employees.

\subsection{The Effect of Performance Measurement Systems, Compensation Systems, and Job Satisfaction Together on Motivation}

Performance measurement and compensation related to employee work motivation where efforts to improve employee motivation, in addition to measuring performance must be accompanied by the provision of fair and appropriate compensation programs. The research results of Herpen et al., (2005); Souza \& Ilse (2018); Alvi \& Mehree (2013) that performance measurement positively and significantly influences employee motivation. Compensation is one thing that is very important to achieve company goals. Efforts to achieve company goals need to have a compensation program to motivate employees to work better. The better the performance measurement system, the compensation system and job satisfaction together - the higher the employee's work motivation.

- H7: There is an influence of performance measurement systems, compensation systems, and job satisfaction together - the work motivation of Yogyakarta KPP Pratama employees.

\subsection{Effect of Performance Measurement Systems on Motivation Mediated by Job Satisfaction}

The implementation of performance measurement is expected to be useful to motivate employees to work and provide opportunities for employees in the aspects of extrinsic motivation and intrinsic motivation to recognize, sharpen, develop, and convey the ideas of initiative and their thoughts and potential. It is hoped that the potentials of its employees will develop the best work performance for the development of the company and itself, especially to face the current era of globalization. Efforts to increase employee motivation, in addition to measuring performance must be accompanied by the provision of fair and appropriate compensation programs. Locke (2004) also explains that one's job satisfaction depends on the discrepancy between should be (expectation needs or value) and what according to his feelings or perceptions have 
been obtained through work. According to Locke (2004) an individual will feel satisfied or dissatisfied is something personal, depending on how he prepares for a match or conflict between the desire and the outcome of its release. The research results of Herpen et al., (2005); Souza \& Ilse (2018) that performance measurement influences employee motivation indirectly through job satisfaction. Personal \& Dhyah research results (2014); Alvi \& Mehree (2013) that work measurement has a positive and significant effect on the work motivation of employees of PT. Enseval Putera Megatrading Surabaya Branch 2 through job satisfaction. The better the performance measurement system, the higher employee motivation is mediated by job satisfaction.

- H8: There is an influence of the performance measurement system on the work motivation of Yogyakarta KPP Pratama employees which is mediated by job satisfaction.

\subsection{Effect of Compensation Systems on Motivation Mediated by Job Satisfaction}

Compensation relates to employee work motivation where compensation programs on transparency, fairness, and controllability generally aim at the interests of the company and the employees themselves. So that these goals can be achieved and provide satisfaction for all parties, the compensation program should be based on the principles of fairness, fairness and compliance with labor laws. Providing compensation is one thing that is very important to achieve company goals. Efforts to achieve company goals need to have a compensation program to motivate employees to work better. If the services provided are large enough, the manager will easily motivate his subordinates (Hasibuan, 2008).

According to Herzberg (Robbins \& Mary, 2008) job satisfaction and job dissatisfaction are different things. Satisfaction and dissatisfaction with the work is not a continuous variable. This theory formulates the characteristics of work into two groups namely; satisfies or motivators and dissatisfies. Satisfies are factors or situations that are needed as a source of job satisfaction consisting of interesting work, full of challenges there are opportunities for achievement, the opportunity to get awards and promotions. Fulfillment of these factors will cause satisfaction, but not fulfilling these factors does not always lead to dissatisfaction. Dissatisfies (hygiene factors) are factors that are the source of dissatisfaction consisting of salary / wages, supervision, interpersonal relations, working conditions and status. This factor is needed to meet the biological impulses as well as the basic needs of employees. If these factors are not met employees will not be satisfied. If the magnitude of these factors is sufficient to meet these needs, employees will not be disappointed even if they are not satisfied. The research results of Herpen et al., (2005); Souza \& Ilse (2018); Alvi \& Mehree (2013) that compensation affects employee motivation indirectly through job satisfaction. The better the compensation system, the higher employee motivation will be mediated by job satisfaction.

- H9: There is an effect of the compensation system on the work motivation of Yogyakarta KPP Pratama employees which is mediated by job satisfaction.

\section{Research Methods}

In this study the population is all employees (ASN) KPP Pratama Yogyakarta, amounting to 109 people. All censuses are subject to research.

\subsection{Performance Measurement System}

The performance measurement system described by Idowu (2017) develops Gardner's explanation (2008) and describes performance measurement as an evaluation of individual work with the main objective of achieving objective personnel decisions. It is also considered a process of obtaining, analyzing, and recording information that revolves around the relative value of employees to the organization.

Idowu (2017) examines the relationship of performance measurement systems with employee motivation. Idowu (2017) measures a good performance measurement system with several indicators as explained below:

- Level of importance

- Assessed by the supervisor

- Effective self-measurement

- The most effective explicit goal

- Rewards motivate employees more than awareness

- Associated with compensation and incentives

- Able to reach the goal

- Job descriptions are easy to understand

- Able to help identify strengths and weaknesses of the company

- Promotion based on performance measurement

\subsection{Compensation System}

Compensation System is the provision of all benefits received by employees in lieu of services that have been provided (Herpen et al., 2005).

Herpen et al., (2005) measure compensation systems with several indicators as to the following description:

- Clarity by determining salary

- Clarity with promotion

- Clarity of criteria about promotion

- Appreciation of employees who do a good job

- Compensation of compensation received with performance performed 
- Compensation received is better when compared to what can be obtained at other companies doing the same work

- Appropriate promotion of promotions for employees

- Appropriate compensation received if working harder.

- Suitability of promotion is determined by the ability of each individual.

\subsection{Job Satisfaction}

Job satisfaction. Lund (2003) adds the definition of job satisfaction by stating that the function of the perceived relationship between what a person wants from his job and what he feels as an offer Job satisfaction is a positive emotional state of someone arising from something the work has done (Luthans, 2005). Measurement of job satisfaction measured by indicators from Lund (2003) include:

- Satisfaction with work in the office

- Satisfaction with my coworkers

- Satisfaction with supervisors

- Satisfaction with my salary

- Satisfaction with promotion opportunities in the company

\subsection{Work Motivation}

Herpen et al., (2005) discuss motivation which is seen from intrinsic versus extrinsic motivation (Calder \& Staw, 1975). Extrinsic motivation is motivation that is obtained with satisfaction that is influenced by external needs and thus for example is stimulated by monetary rewards (Frey (1997). Motivation itself is measured by indicators that include (Herpen, 2005):

- By working harder motivates employees to get optimal compensation

- Employees find a good compensation system so they can motivate themselves

- Good promotions stimulate employees to work hard

- Employees are satisfied with a predetermined compensation system

- Employees are satisfied with promotions held at the office

- Employees know that the office feels it is important to have a solid and clear compensation system

- Employees are enthusiastic about their salary levels

- If it is really necessary, employees are ready to work overtime even if not specifically paid.

- Employees often have to force themselves to work

- Employees get a lot of satisfaction from the work I do

- Employees are very satisfied with their work

- The work done is in accordance with the business

- Employees are enthusiastic about their work

- Employees work with enthusiasm to get the job done

\section{Result}

\subsection{Test Validity}

The results of the validity test based on calculations using SPSS for windows produce that the results of the validity test of each question item are concluded valid or a significance value $\leq 0.05$.

\subsection{Reliability Test}

The method that will be used to perform the reliability test is to correlate the score between the questions with the total construct score or variable. As for the reliability test that will be used in this study is to use the SPSS facility, namely the Cronbach Alpha statistical test. A construct or variable is declared reliable, if the Cronbach Alpha value $>0.60$ (Ghozali, 2016). From the results of data analysis concluded that the question items are reliable or $\geq 0.60$.

\subsection{Inferential Analysis}

\begin{tabular}{|c|c|c|c|}
\hline \multicolumn{4}{|c|}{ Pengujian Mediasi } \\
\hline Arah Pengaruh & Koefisien Regresi & Indirect Effect & Total Effect \\
\hline$X_{1} \rightarrow Y_{1}$ & 0,324 & - & - \\
\hline$X_{2} \rightarrow Y_{1}$ & 0,596 & - & - \\
\hline$X_{1} \rightarrow Y_{2}$ & 0,311 & - & - \\
\hline$X_{2} \rightarrow Y_{2}$ & 0,235 & - & - \\
\hline$Y_{1} \rightarrow Y_{2}$ & 0,306 & - & - \\
\hline$X_{1} \rightarrow Y_{1} \rightarrow Y_{2}$ & - & 0,099 & 0,414 \\
\hline$X_{2} \rightarrow Y_{1} \rightarrow Y_{2}$ & - & 0,182 & 0,417 \\
\hline
\end{tabular}

Table 1: Result Test 


\subsection{Regression Analysis Model 1}

From the results of multiple linear regression analysis obtained the results of the regression coefficient, and pvalue. The results of linear regression analysis obtained by the calculation of multiple linear regression that connects the performance measurement system variables and compensation variables to the job satisfaction variable with the following equation:

$\mathrm{Y} 1=0.324 \mathrm{X} 1+0.596 \mathrm{X} 2$

\subsubsection{Testing the Effect Coefficient ( $\mathrm{t}$ test)}

\subsubsection{Test the Effect of Performance Measurement Systems on Job Satisfaction}

The results of the calculation of the data processing, there is an effect coefficient of 0.324 and a statistical value of 5.666 which corresponds to a significance value of 0.000 (calculation results). So, the performance measurement system has a positive and significant effect on job satisfaction of KPP Pratama Yogyakarta employees. Thus, the first hypothesis is accepted (proven).

\subsubsection{Test The Effect of the Compensation System on Job Satisfaction}

The results of the calculation of data processing, there is an effect coefficient of 0.596 and a statistical value of 10.420 which corresponds to a significance value of 0.000 (calculation results). So, the compensation system has a positive and significant effect on job satisfaction of KPP Pratama Yogyakarta employees. Thus, the second hypothesis is accepted (proven).

\subsubsection{Coefficient of Determination (R2)}

Based on the results of the SPSS data processing, a coefficient of determination value of 0.735 is obtained. This means that $73.5 \%$ of the job satisfaction of KPP Pratama Yogyakarta employees is influenced by the two independent variables consisting of performance measurement systems and compensation systems. While the remaining $26.5 \%$ is influenced by other variables not included in this study.

\subsubsection{Simultaneous Significance Test (Test F)}

Based on the results of data processing calculations, the significance probability value of 0,000 was obtained. Because the significance level value $<0.05(\alpha=5 \%)$, then $\mathrm{H} 0$ is rejected, this means that simultaneously the performance measurement system variable and the compensation system have a significant effect on the dependent variable, namely job satisfaction.

\subsection{Regression Analysis Model 2}

From the results of multiple linear regression analysis obtained the results of the regression coefficient, and pvalue. The results of linear regression analysis can produce the following equation:

$\mathrm{Y} 2=0.311 \mathrm{X} 1+0.235 \mathrm{X} 2+0.506 \mathrm{Y} 1$

\subsubsection{Testing the Effect Coefficient ( $\mathrm{t}$ test)}

The results of the calculation of the data if there is a coefficient of 0.311 and a statistical value of 3.579 which corresponds to a significance value of 0.001 . So, the performance measurement system affects the work motivation of Yogyakarta KPP Pratama employees. Thus, the third hypothesis is accepted.

\subsubsection{Test the Compensation System for Work Motivation}

The result of data processing calculation is that there is a coefficient of 0.235 and a statistical value of 2.098 which corresponds to a significance value of 0.038 . So, the compensation system affects the work motivation of Yogyakarta KPP Primary employees. Thus, the fourth hypothesis is accepted.

\subsubsection{Test Job Satisfaction on Work Motivation}

The results of the calculation of data processing, there is a coefficient of 0.306 and a statistical value of 3.067 which corresponds to a significance value of 0.003 . So, job satisfaction affects the work motivation of Yogyakarta KPP Primary employees. Thus, the fifth hypothesis is accepted.

\subsubsection{Coefficient of Determination (R2)}

Based on the results of SPSS data processing, the coefficient of multiple determination values obtained is 0.552 . This means that $55.2 \%$ of the work motivation of KPP Pratama Yogyakarta employees is influenced by the three independent variables consisting of performance measurement systems, compensation systems and job satisfaction. While the remaining $44.8 \%$ is influenced by other variables not included in this study.

\subsubsection{Simultaneous Significance Test (Test F)}

Based on the results of data processing calculations, the significance probability value of 0,000 was obtained. Because the significance level value $<0.05(\alpha=5 \%)$, then $\mathrm{H} 0$ is rejected, this means that simultaneously the performance measurement system variables, Compensation system variables and job satisfaction variables have a significant influence on the dependent variable namely work motivation. 


\subsubsection{Path Analysis}

Path analysis model is a pattern of causal relationships or a set of hypothesized causal asymmetric among the variables (Ghozali 2016). Path analysis of the influence between these variables can be described as follows:

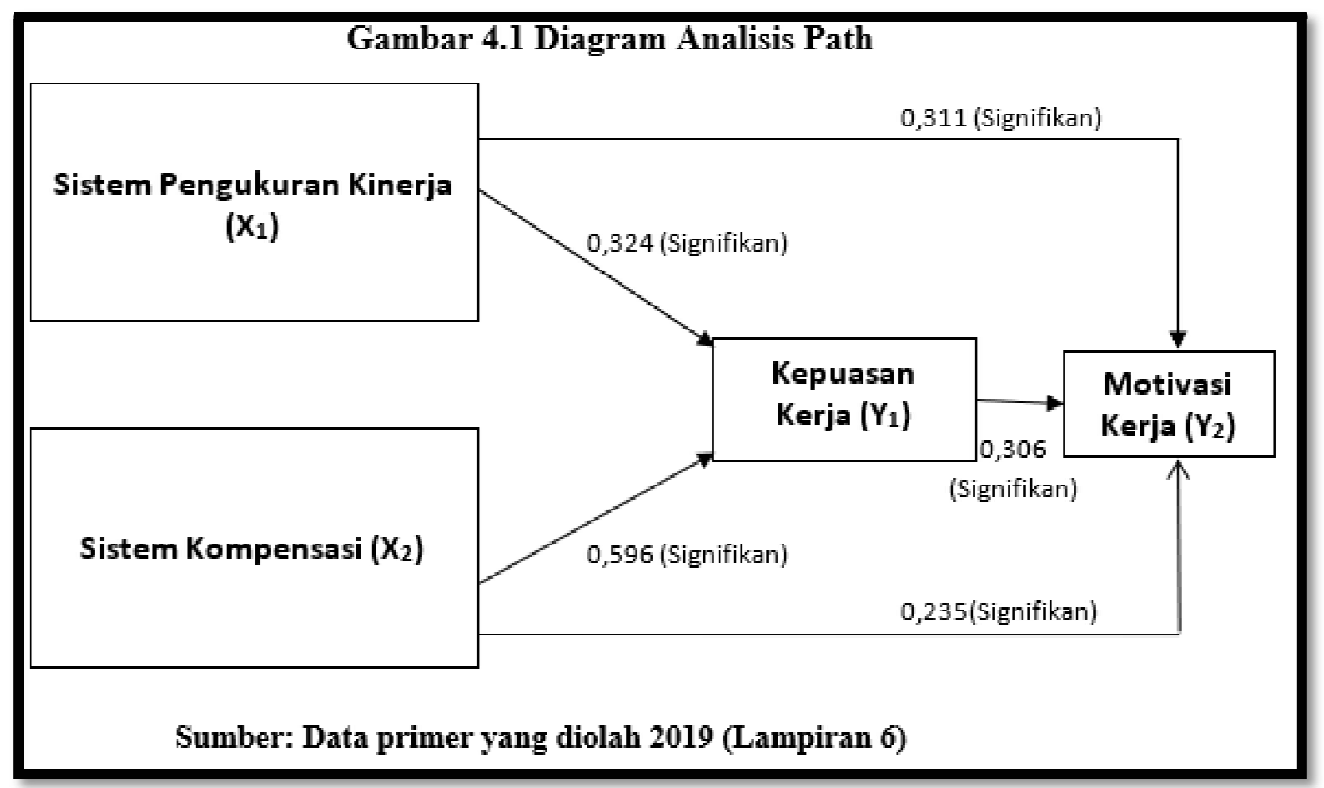

Figure 1

Based on the test above, a summary table of research results is made with the following details:

Testing mediation hypotheses is calculated using a procedure developed by Sobel (1982) or Sobel Test. To calculate the test, the following data are needed:
1). $\quad X_{1} \rightarrow \mathrm{Y}_{1} \quad\left(\mathrm{a}_{1}\right) \quad=0,324$
2). $\quad X_{2} \rightarrow Y_{1}\left(a_{2}\right) \quad=0,596$
3). $\mathrm{Y}_{1} \rightarrow \mathrm{Y}_{2}$ (b) $\quad=0,306$
4). $\mathrm{SE}_{\mathrm{a} 1} \quad=0,061$
5). $\mathrm{SE}_{\mathrm{a} 2} \quad=0,053$

4.5.4.1. Testing Mediation Effects 1

$$
=\frac{a b}{z=\frac{a, 324 \times 0,306}{\left.\sqrt{\left(b^{2} S E a^{2}\right)+\left(a^{2}\right.} S E b^{2}\right)}}
$$

$z=3,18197361$

From the calculation of the sobel test above obtained $\mathrm{z}$ value of 3.18197361, because the $\mathrm{z}$ value of 3.18197361>1.96. Then prove that job satisfaction is able to mediate the effect of performance measurement systems on work motivation.

\subsubsection{Testing Mediation Effects 2}

$$
\begin{gathered}
z=\frac{a b}{\left.\sqrt{\left(b^{2} S E a^{2}\right)+\left(a^{2}\right.} S E b^{2}\right)} \\
=\frac{0,596 \times 0,306}{\left.\sqrt{\left(0,306^{2} \times 0,053^{2}\right)+\left(0,596^{2}\right.} \times 0,077^{2}\right)} \\
z=3,74693418
\end{gathered}
$$

From the calculation of the sobel test above obtained $z$ value of 3.74693418 , because the $z$ value of $3.74693418>1.96$ with a significance level of $5 \%$ then proves that job satisfaction is able to mediate the effect of the compensation system on work motivation.

\subsection{Classic Assumption Test}

\subsubsection{Data Normality Test}

Based on data analysis that the significance value is greater than 0.05 , it can be concluded that the residual data are normally distributed. 


\subsubsection{Multicollinearity Test}

Based on the data analysis, it can be concluded that there is no multicollinearity between independent variables in the regression model, because none of the independent variables has a tolerance value smaller than 0.10 and a VIF value of more than 10 (ten).

\subsubsection{Heterokedasticity Test}

Heteroscedasticity test results show that the correlation value of the three independent variables with Unstandardized Residual has a significance value $\geq 0.05$. Because the significance is more than 0.05 , it can be concluded that there is no heteroscedasticity problem in the regression model.

\section{Discussion}

- Performance measurement system has a positive and significant effect on job satisfaction

- Performance measurement system has a positive and significant effect on job satisfaction. Data processing in this study that analyzes the effect of performance measurement systems with job satisfaction is not in accordance with the hypothesis which states that there is a positive influence between performance measurement systems and job satisfaction. This means showing that employees who have a high-performance measurement system will have less organizational job satisfaction.

- The compensation system has a positive and significant effect on job satisfaction

- The compensation system has a positive and significant effect on job satisfaction. Processing data in this study that analyzes the effect of the compensation system with job satisfaction in accordance with the hypothesis which states that there is a positive influence between the compensation system and job satisfaction. This means showing that employees who have a higher compensation system then employees get job satisfaction in the organization.

- Performance measurement systems and compensation systems have a positive and significant effect on job satisfaction

- Performance measurement systems and compensation systems have a significant effect on work motivation. Data processing in this study that analyzes the effect between performance measurement systems and compensation systems with job satisfaction in accordance with the hypothesis which states that job satisfaction has a positive effect on work motivation. This means showing that employees who have a performance measurement system and compensation system will be more likely to have less job satisfaction with an organization.

- Performance measurement system has a positive and significant effect on work motivation

- Performance measurement system has a positive and significant effect on work motivation. Data processing in this study analyzes the effect of performance evaluation systems with work motivation in accordance with the hypothesis which states that there is a positive influence between performance measurement systems and work motivation. This means that shows that employees who have a higher performance measurement system employee get work motivation in the organization.

- The effect of the compensation system has a positive and significant effect on work motivation

- Compensation system has a positive but not significant effect on work motivation. Data processing in this study that analyzes the effect of compensation systems with work motivation is not in accordance with the hypothesis which states that there is a positive influence between compensation systems and work motivation. This means showing that employees who have a higher compensation system then employees tend to lack work motivation in the organization.

- Job satisfaction has a positive and significant effect on work motivation. Job satisfaction has a significant effect on work motivation.

- Data processing in this study that analyzes the effect between job satisfaction and work motivation in accordance with the first hypothesis which states that job satisfaction has a positive effect on work motivation. This means showing that employees who have job satisfaction will be more likely to have a high level of work motivation towards an organization. Thus, in the process of working within the organization, employees must feel comfortable and fair so that satisfaction with their work can motivate employees to improve work in the form of on time and can meet targets in the organization.

- Performance measurement systems, compensation systems and job satisfaction have a positive and significant effect on work motivation

- Performance measurement systems, compensation systems and job satisfaction have a significant effect on work motivation. Data processing in this study that analyzes the effect between performance measurement systems and compensation systems with job satisfaction in accordance with the hypothesis which states that job satisfaction has a positive effect on work motivation. This means showing that employees who have a performance measurement system and compensation system will be more likely to have less job satisfaction with an organization.

- Job satisfaction can mediate a positive and significant relationship between performance measurement systems and work motivation.

- These results are due to employees at KPP Pratama having high job satisfaction so that they are able to mediate performance measurement systems on work motivation. 
- Job satisfaction can mediate a positive and significant relationship between compensation systems and work motivation.

- These results indicate that Yogyakarta KPP Pratama employees have high job satisfaction so that they are able to mediate the compensation system for work motivation.

\section{References}

i. Ainnisya, Rima Nur \& Isnurrini Hidayat Susilowati. (2018). Pengaruh Pengukuran Kinerja terhadap Motivasi Kerja Karyawan pada Hotel Cipta Mampang Jakarta Selatan.Widya Cipta.Vol.2(1):133-140.

ii. Al Fatta, Hanif. (2007). Analisis dan Perancangan Sistem Informasi untuk Keunggulan Bersaing Perusahaan dan Organisasi Modern. Yogyakarta: Andi.

iii. Almohtaseb, Ahmad Ali, Mohammad Adnan Almahameed, Dua'a Shaher Tobeery, \& Hisham Kareem Shaheen. (2017). The Impact of Performance Management Sistem on Employee Performance: The Moderating Role of Balance Scorecard Usage. International Review of Management and Business Research. Vol.6(2):681-691.

iv. Alvi, Mohsin Alvi, Mehreen Surani, \& Saneea Hirani. (2013). The Effect of Performance Evaluation on Employee's Job Satisfaction in Pakistan International Airlines Corporation. MPRA Paper. No.46415:1-30.

v. Andini, Rita. (2006). Analisis Pengaruh Kepuasan Kerja, Kepuasan Gaji, Komitmen Organisasional terhadap Turnover Intention.Tesis. Program Pasca Sarjana Magister Manajemen Universitas Diponegoro Semarang.

vi. Arikunto, Suharsini. (2013). Prosedur Penelitian Suatu Pendekatan Praktik. Jakarta: Rineka Cipta.

vii. Armstrong, M. (2009) Armstrong's Handbook of Performance Management: An EvidenceBased Guide to Delivering High Performance. London: Kogan Page Publishers.

viii. As'ad, M. (2002). Psikologi Industri. Yogyakarta: Liberty.

ix. Bakotić, Danica. (2016). Relationship between Job Satisfaction and OrganizationalPerformance. Economic Research-Ekonomska Istraživanja. Vol 29(1):1-13.

x. Baron, Rueben M., \& David A. Kenny. (1986). The Moderator-Mediator Variabel Distinction in Social PsychologicalResearch: Conceptual, Strategic, and Statistical Considerations. Journal of Penality and Social Psychology. Vol. 51(6):1173-1182.

xi. Bernardin, H.J., \&J.E.A. Russel. (1993). Human Resources Management. Singapore: McGraw Hill Inc.

xii. Busro, Muhamamad. (2018). Teori-teori Manajemen Sumber Daya Manusia.Jakarta:Prenada Media.

xiii. Cook, J., \& Crossman, A. (2004). Satisfaction with performance appraisal sistems: A study of role perceptions. Journal of Managerial Psychology, 526-541.

xiv. Cook, J., \& Crossman, A. (2004). Satisfaction with performance appraisal sistems: A study of role perceptions. Journal of Managerial Psychology, 526-541.

xv. Danim, Sudarwan. (2004). Motivasi Kepemimpinan \& Efektivitas Kelompok. Jakarta: Rineka Cipta.

xvi. Darma, P. S., \& Supriyanto, A. S. (2018). The Effect Of Compensation On Satisfaction And Employees Performance. Management and Economics Journal, 69-77.

xvii. Dessler, Gary. (2004). Manajemen Sumber Daya Manusia. Jakarta: Indeks.

xviii. Direktorat Jenderal pajak. (2019, Januari 25). Pofil. Retrieved from www.pajak.go.id: https:/ / www.pajak.go.id/

xix. Ferreira, D., \& Baidya, T. (2016). The Impact of Compensation Sistems on the Motivation of Teachers of a Higher Education Institution. International Journal of Business Management and Economic Research(IJBMER, 793-803.

xx. Ferreira, D., \& Baidya, T. (2016). The Impact of Compensation Sistems on the Motivation of Teachers of a Higher Education Institution. International Journal of Business Management and Economic Research(IJBMER, 793-803.

xxi. Gaol, J.L. (2008). Sistem Informasi Manajemen. Jakarta: Gramedia Pustaka Utama.

xxii. Gardner, C.E. (2008) Employee evaluation: is it worth the effort? DVM, 18(5), pp. 647

xxiii. Ghazanfar,Faheem, Shuai Chuanmin, Muhammad Mahroof Khan, \& Mohsin Bashir. (2011). Study of Relationship between Satisfaction with Compensation and Work Motivation. International Journal of Business and Social Science. Vol.2(1):120-131.

xxiv. Ghozali, Imam. (2016). Ekonometrika; Teori Konsep dan Aplikasi dengan SPSS IBM 25. Semarang: Badan Penerbit Universitas Diponegoro.

xxv. Griffin. (2004). Komitmen Organisasi. Jakarta: Erlangga

xxvi. Gujarati, Damodar. (2009). Econometrics. New York: Mc Graw Hill Inc.

xxvii. Handoko, T. Hani. (2008). Manajemen. Yogyakarta: BPFE.

xxviii. Hariandja. (2002. Manajemen Sumber Daya Manusia. Jakarta: Grasindo.

xxix. Haryani, Sagita Sukma, Djamhur Hamid, \& Heru Susilo. (2015). Pengaruh Kompensasi terhadap Motivasi Kerja dan Kinerja (Studi pada Karyawan PT. Telekomunikasi Indonesia, Tbk Malang). Jurnal Administrasi Bisnis (JAB). Vol.25(1):1-7.

xxx. Hasibuan, Malayu SP. (2008). Manajemen Sumber Daya Manusia. Yogyakarta: BPFE-UGM.

xxxi. Herpen, Marco Van, Mirjam Van Praag, \& Kees Cools.(2005). The Effects of Performance Measurement and Compensation on Motivation: An Empirical Study. De Economist. Vol.10(153):303-329.

xxxii. Idowu, A. (2017). Effectiveness of Performance Appraisal Sistem and its Effect on Employee Motivation. Nile Journal of Business and Economics, 15-39.

xxxiii. Jackson, Alfonsus \& James AF. Mathis. (2006). Manajemen. Jakarta: Erlangga.

xxxiv. Jogiyanto. (2005). Analisis dan Desain Sistem Informasi. Yogyakarta: Andi.

xxxv. Kreitner, Robert \& Angelo Kinicki. (2007). Organizational Behavior. 7th ed. New York: McGraw Hill. Avenues of The Americas. 
xxxvi. Lai, H. H. (2011). The influence of compensation sistem design on employee satisfaction. Journal of Business Managemen, 10718-10723.

xxxvii. Lira. (2014). Satisfaction with a performance appraisal sistem in the Portuguese public sector: The importance of perceptions of justice and accuracy. Review of Applied Management Studies .

xxxviii. Locke, E.A. (2004). The Nature and Causes of Job Satisfaction. NewYork: John Wiley and Sons.

xxxix. Lund, D. (2003). Organizational Culture and Job Satisfaction. Journal of Business and Industrial Marketing, 219236 And Employees Performance. Management and Economics Journal, 69-77.

xl. Luthans, F. (2005). Organizational Behaviour. Ninth Edition. USA: McGraw-Hill Companies Inc.

xli. $\quad$ Madura, Jeff. 2001. Pengantar Bisnisjilid 2. Jakarta: Salemba Empat.

xlii. $\quad$ Mangkunegara, A.P. (2005). Evaluasi Kinerja. Bandung: Refika Aditama

xliii. Marwanto, Tri Budi Marwanto, \& Riyadi Nugroho. (2014). Pengaruh Kompensasi dan Lingkungan Kerja terhadap Motivasi dan Disiplin Kerja Prajurit di Satuan Kerja KRI X Armada RI Kawasan Timur. JMM17 Jurnal Ilmu Ekonomi \& Manajemen.Vol.1(1):74-82.

xliv. Milkovich, George T,. \& Newman, Jerry M. (2002). Compensation. International Edition. 7th Edition. New York: Mc Graw-Hill Irwin.

xlv. Mondy, R. Wayne. (2008). Manajemen Sumber Daya Manusia. Jakarta: Erlangga.

xlvi. Morgeson, F., Campion, M., \& Maertz, C. (2001). Understanding Pay Satisfaction: The Limits Of A Compensation Sistem Implementation. Journal Of Business And Psychology, 133-148.

xlvii. Naji; Jamal, A., Ben Mansour, \& Lecl, A. (2015). Performance Appraisal Sistem and Employee Satisfaction: The role of trust towards supervisors. Journal of Human Resources Management and Labor Studies, 40-53.

xlviii. Nazir, Mohammad. (2011). Metode Penelitian. Bogor: Ghalia Indonesia.

xlix. Newman, Jerry M. (2005). Compensation. New York: McGraw-Hill.

l. Ngatemin \& Wanti Arumwanti. (2013). Pengaruh Kompetensi dan Kompensasi terhadap Motivasi Kerja Karyawan Hotel di Kabupaten Karo Provinsi Sumatera Utara.Jurnal Riset Akuntansi dan Bisnis. Vol.13(1):80-92.

li. Nitisemito, Alex S. (2005). Manajemen Personalia. Jakarta: Ghalia Indonesia

lii. Nursalam. (2009). Konsep dan Penerapan Metodologi Penelitian Ilmu Keperawatan. Pedoman Skripsi, Tesis dan Instrumen Penelitian Keperawatan. Jakarta: Salemba Medika.

liii. Pangaribuan, Wanapri. (2010). Sistem Pengendalian Pembangunan Pendidikan Berbasis Logika Kabur (Fuzzy Logic). Generasi Kampus. Vol.3(1):45-54.

liv. Praven, Gupta, (2008). Service Scorecard. New Jersey: Pearson Education Inc. FT Press Upper Saddle River.

lv. Prawirosentono, Suyadi. (2008). Kebijakan Kinerja Karyawan. Yogyakarta: BPFE.

lvi. Pribadi, Jessica Avelina \& Dhyah Harjanti. (2014). Pengaruh Pengukuran Prestasi Kerja terhadap Motivasi Kerja Karyawan dengan Kompensasi Sebagai Variabel Intervening pada PT. Enseval Putera Megatrading Cabang Surabaya 2. Agora. Vol.2(1):1-8.

lvii. Rizal, M., Idrus, S., Djumahir, \& Rahay. (2014). Effect of Compensation on Motivation, Organizational Commitment and Employee Performance (Studies at Local Revenue Management in Kendari City). International Journal of Business and Management Invention, 64-79.

lviii. Rizal,Muhamad Rizal, M Syafiie Idrus, Djumahir, \& Rahayu Mintarti.(2016).Effect of Compensation on Motivation, OrganizationalCommitment and Employee Performance (Studies at LocalRevenue Management in Kendari City). International Journal of Business and Management Invention. Vol.3(2):64-79.

lix. Robbins, P. Stephen \& Mary Coulter. (2008). Perilaku OrganisasiKonsep. Kontroversi. Aplikasi. Jakarta: Prenhallindo.

lx. $\quad$ Robbins SP, \& Jugde 2008. Perilaku Organisasi Buku 2, Jakarta: Salemba Empat.

lxi. Santoso, Singgih. (2017). Metode Penelitian. Jakarta: Elek Media Komputindo.

lxii. Siagian, Sondang P. (2006. Manajemen Sumber Daya Manusia. Jakarta: Bumi Aksara.

lxiii. Simamora, Henry. (2006). Manajemen Sumber Daya Manusia. Yogyakarta: STIE YKPN.

lxiv. Souza, Guilherme Eduardo de \& Ilse Maria Beuren. (2018). Impact of an enabling Performance MeasurementSistem on Task Performance and Job Satisfaction. Revista Contabilidade \& Finanças. Vol.29(77):115.

lxv. Spector, P. E. (1997). Job Satisfaction : Application, assesment, cause, and consequences. Thousand Oaks, CA: Sage.

lxvi. Sudiardhita,Ketut IR, Saparuddin Mukhtar, Budi Hartono, Herlitah, Tuty Sariwulan, \&Sri Indah Nikensari.(2018).The Effect of Compensation, Motivation of Employee and Work Satisfaction to Employee Performance PT. Bank XYZ (Persero) TBK. Academy of Strategic Management Journal. Vol.17(4):1-7.

lxvii. Sugiyono. (2017). Metode Penelitian Kualitatif dan Kuantitatif. Bandung: Alfabeta.

lxviii. Supranto, John. (2003). Statistik Teori dan Aplikasi. Jakarta: Erlangga.

lxix. Thoha, M. (2008). Kepemimpinan dalam Menajemen.Jakarta: PT Raja Grafindo Perkasa.

lxx. Ukko, Juhani, Jarkko Tenhunen, Hannu Rantanen. (2008). The Impacts of Performance Measurement on TheQuality of Working Life. Int. J. Business Performance Management. Vol.10(1):87-98.

lxxi. Wahyudi, Bambang. (2002). Manajemen Sumber Daya Manusia. Bandung: Sulita.

lxxii. Widodo, Untung. (2011). Pengaruh Komunikasi dan Disiplin Kerja terhadap Kinerja Karyawan pada SMK Pelita Nusantara 1-2 Semarang. Fokus Ekonomi. Vol. 6(2):99-114.

lxxiii. Ying, Ying Zhang. (2013). The Impact of Performance Management Sistem on Employee Performance. Thesis. University of Twente. 
lxxiv. Ari Warokka, Cristina G. Gallato and Thamendren (2012). Organizational Justice in Performance Appraisal Sistem and Work Performance: Evidence from an Emerging Market. IBIMA Publishing Journal of Human Resources Management Research Vol. 2012.

lxxv. Paul W. Thurston and Laurel McNall (2010) "Justice perceptions of performance appraisal practices", Journal of Managerial Psychology, Vol. 25 No. 3, pp. 201-228 